DOI: $10.21802 /$ artm.2019.2.10.93.

УДК 616.8-936.22(477.87)"2017”

\title{
ЕПІДЕМІОЛОГІЯ НЕВРОЛОГІЧНИХ ЗАХВОРЮВАНЬ У ЗАКАРПАТСЬКІЙ ОБЛАСТІ У 2017 РОЦІ
}

\author{
I.M. Рогач, М.М. Смірнов, В.В. Жорник
}

Ужгородський наиіональний університет, кафедра соиіальної медицини та гігієни, м. Ужгород, Украйна,

ORCID ID: 0000-0001-6112-3934,

ORCID ID: 0000-0002-9478-4787,

ORCID ID: 0000-0002-3795-2166,

e-mail:mykyta.smirnov@gmail.com

Резюме. Проблема неврологічних захворювань є вкрай важливою: вони належать до найбільш розповсюджених захворювань ХХІ століття, і більшість із них призводить до довготривалих стійких неврологічних дефіцитів. Вивчення регіональної епідеміології неврологічної патології може сприяти оптимізації управління установами охорони здоров'я з даного питання та раціональному розподілу наявних та потенційних ресурсів. Метою нашого дослідження було вивчення та аналіз епідеміології неврологічних захворювань серед дорослого населення Закарпатської області у 2017 році у розрізі адміністративно-територіальних одиниць. Для отримання інформації щодо кількості випадків захворювань і демографічної обстановки нами було проаналізовано звіти (форма №12) установ охорони здоров'я MO3 України, що надавали медичну допомогу дорослому населенню Закарпатської області з неврологічною патологією в 2017 році, та статистичний бюлетень Головного управління статистики в Закарпатській області. На наступному етапі було підраховано загальну та первинну захворюваність на неврологічну патологію з визначенням питомої ваги останньої та наступним аналізом отриманих показників. Було визначено, що в Закарпатській області відмічається подібна до України тенденція розподілу питомої ваги окремих груп захворювань в структурі загальної захворюваності на неврологічну патологію. Значення показників на Закарпатті у 2017 році були значно меншими, ніж у країні загалом. Поширеність неврологічної патології загалом становила 4902,4 на 100 тис. нас. (на 58,8 \% менше), цереброваскулярних захворювань 2135,3 на 100 тис. нас. (на 70,5 \% менше), захворювань нервової системи - 2767,1 на 100 тис. нас. (на 40,6 \% менше). Також було відмічено значні коливання значень показників у розрізі районів.

Ключові слова: епідеміологія, неврологічні захворювання, захворюваність, доросле населення, поширеність.

Вступ. Патологія нервової системи належить до найбільш розповсюджених захворювань XXI століття. Збільшення кількості випадків неврологічної патології (НП) в Україні зумовлено такими факторами як старіння населення, метаболічний синдром, несприятливий стан навколишнього середовища, хронічний стрес, імунна недостатність тощо [1].

Відповідно до офіційних даних Центру медичної статистики МО3 України, в країні у 2017 році було зареєстровано 4497718 пацієнтів з НП, що в 1,09 рази більше показника 2014 року (4130479 паціснтів). Перше місце по кількості зареєстрованих випадків захворювань, як і раніше, посідають цереброваскулярні захворювання (Ц3) (2521601 пацієнт), хоча й кількість випадків дещо зменшилась порівняно з 2014 роком (2557591 пацієнт). Майже третина хворих даної групи - це населення працездатного віку [2, 3].

Поширеність НП в Україні у 2017 році становила 11905,1 на 100 тис. населення, з якої 7246,1 на 100 тис. нас. відносяться до ЦЗ, і 4659 на 100 тис. нас. - до розладів нервової системи [2, 3]. Ураження судин головного мозку (мозкові інсульти) заслуговують особливої уваги серед ЦЗ. У нашому попередньому дослідженні виявлено, що в Закарпатській області у
2017 році мозкові інсульти були на 21,7 \% менш поширені, ніж в Україні (217,6 на 100 тис. нас. і 278,7 на 100 тис. нас. відповідно) [4].

Окрім ЦЗ, у структурі НП найбільш актуальними та соціально важливими є хвороби периферичної нервової системи, розсіяний склероз, хвороба Паркінсона й епілепсія [1].

Обгрунтування дослідження. Більшість захворювань, що входять в структуру НП, розвиваються в осіб працездатного віку та призводять до тривалої тимчасової непрацездатності або інвалідності, i, як наслідок, опосередковано впливають на соціальноекономічний розвиток країни. Саме тому, разом із покращенням якості та доступності діагностики і лікування НП, важливими є удосконалення первинної і вторинної профілактики даних захворювань і створення сприятливих для життєдіяльності індивіда умов навколишнього середовища [5]. Оскільки збереження здоров'я $\epsilon$ необхідною умовою успішного виконання першочергових вимог економічного та соціального розвитку країни, інформація про первинну та загальну захворюваність населення набуває особливого значення, зокрема на регіональному рівні [7]. 
Метою дослідження було вивчення й аналіз епідеміології НП серед дорослого населення Закарпатської області у 2017 році в розрізі адміністративно-територіальних одиниць.

Матеріали i методи дослідження. Для отримання інформації щодо кількості випадків захворювань і демографічної ситуації нами було проаналізовано звіти (форма №12) установ охорони здоров'я MO3 України, що надавали медичну допомогу дорослому населенню Закарпатської області 3 неврологічною патологією в 2017 році, та статистичний бюлетень Головного управління статистики в Закарпатській області. На основі виокремлених даних було підраховано епідеміологічні показники, а саме поширеність захворювань (загальну захворюваність) і первинну захворюваність із визначенням питомої ваги останньої за допомогою методів біостатистичного аналізу, реалізованих в програмному забезпеченні Excel 2016 (Microsoft, Redmond, US).

НП було визначено як таку, що включала дві основні групи: ЦЗ (I60-I69) і хвороби нервової системи (G00-G99). У структурі останньої було виокремлено запальні захворювання центральної нервової системи (ЦНC) (G00, G03, G04, G06, G08, G09), хворобу Паркінсона (G20), розсіяний склероз (G35), епілепсію та епілептичний стан (G40, G41), минущі транзиторні церебральні ішемічні стани та пов'язані 3 ними синдроми (G45), захворювання периферичної нервової системи (ПНС) (G50-G52, G54, G56-G58, G60-G62, G64, G70), і неуточнені розлади вегетативної нервової системи (G90.9).

Результати дослідження та їх обговорення. Поширеність НП у 2017 році серед дорослого населення Закарпатської області становила 4902,4 на 100 тис. нас., що на 58,5 \% менше аналогічного показника в Україні загалом (табл. 1). Первинна захворюваність в області становила 1647,8 на 100 тис. нас., тобто 33,6 \% від загальної. В абсолютних числах це 61697 та 20738 пацієнтів відповідно.

Таблиця 1

Поширеність неврологічної патології серед дорослого населення Закарпатської області та України у 2017 році (на 100 тис. нас.)

\begin{tabular}{|c|c|c|c|c|}
\hline \multicolumn{3}{|r|}{ Захворювання } & $\begin{array}{c}\text { Закарпатська } \\
\text { область }\end{array}$ & Україна [3] \\
\hline \multicolumn{3}{|r|}{ Неврологічна патологія } & 4902,4 & 11801,1 \\
\hline \multirow{9}{*}{3 неї } & церебро & ккулярні захворювання & 2135,3 & 7246,1 \\
\hline & хвороби & рвової системи & 2767,1 & 4555 \\
\hline & \multirow{7}{*}{ З них } & $\begin{array}{l}\text { запальні захворювання центральної нерво- } \\
\text { вої системи }\end{array}$ & 184,4 & 146,3 \\
\hline & & хвороба Паркінсона & 56,8 & 69,6 \\
\hline & & розсіяний склероз & 37,6 & 60,2 \\
\hline & & епілепсія та епілептичний стан & 160,3 & 83 \\
\hline & & $\begin{array}{l}\text { минущі транзиторні церебральні ішемічні } \\
\text { стани }\end{array}$ & 94,7 & 104 \\
\hline & & $\begin{array}{l}\text { захворювання периферичної нервової сис- } \\
\text { теми }\end{array}$ & 834,7 & 1380,9 \\
\hline & & $\begin{array}{l}\text { неуточнені розлади вегетативної нервової } \\
\text { системи }\end{array}$ & 730,9 & 1550,3 \\
\hline
\end{tabular}

Таблиця 2

Епідеміологія хвороб нервової системи і цереброваскулярних захворювань серед дорослого населення Закарпатської області у 2017 році (на 100 тис. нас.)

\begin{tabular}{|l|c|c|c|c|}
\hline \multirow{2}{*}{ Район } & \multicolumn{2}{|c|}{ Хвороби нервової системи } & \multicolumn{2}{c|}{ Цереброваскулярні захворювання } \\
\cline { 2 - 5 } & Поширеність & Захворюваність & Поширеність & Захворюваність \\
\hline Берегівський & 2416,2 & 949,5 & 2391,0 & 521,3 \\
\hline Великоберезнянський & 4645,3 & 1652,8 & 1618,9 & 483,0 \\
\hline Виноградівський & 2102,4 & 1352,6 & 1365,0 & 471,5 \\
\hline Воловецький & 3797,5 & 562,0 & 1801,7 & 219,0 \\
\hline Іршавський & 2849,6 & 1232,1 & 2037,8 & 426,3 \\
\hline Міжгірський & 5907,9 & 2682,0 & 1723,8 & 736,4 \\
\hline Мукачівський & 1154,8 & 327,2 & 3248,5 & 520,1 \\
\hline Перечинський & 2576,8 & 1398,1 & 1084,6 & 285,3 \\
\hline Рахівський & 1872,7 & 905,1 & 1394,8 & 456,3 \\
\hline Свалявський & 1128,0 & 670,9 & 1085,9 & 621,6 \\
\hline Ужгородський & 2279,9 & 1064,7 & 1751,2 & 461,4 \\
\hline Хустський & 5109,9 & 1981,2 & 2353,2 & 894,0 \\
\hline м. Ужгород & 2573,7 & 814,9 & 3778,1 & 637,7 \\
\hline
\end{tabular}


Перше місце серед НП на Закарпатті у 2017 p., як і в Україні, посідали ЦЗ. Поширеність ЦЗ становила 2135,3 на 100 тис. нас., що відповідає 43,6 \% усіх випадків НП в області. Первинна захворюваність на ЦЗ становила 523 на 100 тис. нас. (питома вага $24,5 \%$ ). За даними офіційної статистики, середне значення поширеності Ц3 в Україні було в 3,4 рази більше, ніж у Закарпатській області [3].

На Закарпатті найвищі значення поширеності Ц3 мали місце в м. Ужгород (3778,1 на 100 тис. нас.), Берегівському (2391 на 100 тис. нас.) і Мукачівському районах (3248,5 на 100 тис. нас.). Найменшою загальна захворюваність була у Перечинському (1084,6 на 100 тис. нас.), Свалявському (1085,9 на 100 тис. нас.) та Виноградівському (1365 на 100 тис. нас.) районах. Питома вага первинної захворюваності була найбільшою у Свалявському районі (57,2 \%, 621,6 на 100 тис. нас.) і найменшою у Воловецькому (12,2 \%, 219 на 100 тис. нас.).

Поширеність захворювань нервової системи загалом по Закарпаттю становила 2767,1 на 100 тис. нас. Первинна захворюваність дорівнювала 1124,8 на 100 тис. нас. 3 питомою вагою - 40,7\%. Найвищі значення поширеності відмічено у Міжгірському (5907,9 на 100 тис. нас.), Великоберезнянському (4645,3 на 100 тис. нас.) і Хустському (5109,9 на 100 тис. нас.) районах. Найменшу поширеність зареєстровано у Свалявському (1128 на 100 тис. нас.), Мукачівському (1154,8 на 100 тис. нас.) та Рахівському (1872,7 на 100 тис. нас.) районах. Питома вага первинної захворюваності на патологію нервової системи була найбільшою у Виноградівському районі (64,3\%, 1352,6 на 100 тис. нас.), а найменшою - у Воловецькому $(14,8 \%, 1352,6$ на 100 тис. нас.). В Україні у 2017 році поширеність захворювань нервової системи була більшою в 1,7 раза, ніж на ЗакарпатTi [3].

В Україні за останні 10 років загальна захворюваність на патологію ПНС зросла в 1,5 раза [1]. В Закарпатській області у 2017 році поширеність захворювань ПНС відмічено на рівні 834,7 на 100 тис. нас. У свою чергу показник первинної захворюваності складав 478 на 100 тис. нас. (питома вага - 57,3\%). Найвищі значення поширеності мали місце в Міжгірському (1935,2 на 100 тис. нас.), Великоберезнянському (1641,5 на 100 тис. нас.) і Перечинському (1269,6 на 100 тис. нас.) районах. Найменшу поширеність відмічено у Воловецькому (95 на 100 тис. нас.), Свалявському (197,4 на 100 тис. нас.) та Мукачівському (258,2 на 100 тис. нас.) районах. Питома вага первинної захворюваності була найбільшою у Свалявському районі $(95,4 \%, 188,3$ на 100 тис. нас.) і найменшою у Воловецькому (13\%, 12,4 на 100 тис. нас.). У країні загалом поширеність захворювань ПНС була більше в 1,7 раза в порівнянні із Закарпаттям [3].

Неуточнені розлади вегетативної нервової системи $є$ щоненайпоширенішими розладами нервової системи в нашій країні [1], і Закарпаття - не виняток. Їх поширеність у 2017 році в даному регіоні становила 730,9 на 100 тис. нас. У свою чергу, вперше в житті дану групу розладів зареєстровано у 186,8 на
100 тис. нас. (питома вага - 25,6 \%). Найвищі значення поширеності спостерігались у Воловецькому (2880,2 на 100 тис. нас.), Хустському (2331,2 на 100 тис. нас.) та Міжгірському (2253,1 на 100 тис. нас.) районах. Найменшу поширеність відмічено у Виноградівському районі (2,5 на 100 тис. нас.), м. Ужгород (3,51 на 100 тис. нас.) та Мукачівському районі (23 на 100 тис. нас.). Питома вага первинної захворюваності на неуточнені розлади вегетативної нервової системи була найбільшою у Свалявському районі $(94,4 \%$, 367,5 на 100 тис. нас.), а в м. Ужгород та Виноградівському районі не було зареєстровано жодних нових випадків захворювань. В Україні у 2017 році поширеність даних захворювань була більшою в 2,1 раза, ніж на Закарпатті [3].

Останнім часом в Україні почастішали випадки запальних захворювань ЦНС [1]. Поширеність запальних захворювань ЦНС в 2017 році в Закарпатській області становила 184,4 на 100 тис. нас., а показник первинної захворюваності мав значення 33,9 на 100 тис. нас. (питома вага - 18,4 \%). Найвищі значення поширеності відмічено у Великоберезнянському районі (720,8 на 100 тис. нас.), Воловецькому (479,3 на 100 тис. нас.) та м. Ужгород (343 на 100 тис. нас.). Найменша поширеність мала місце в Ужгородському (69,7 на 100 тис. нас.), Свалявському (87,8 на 100 тис. нас.) та Виноградівському (89,2 на 100 тис. нас.) районах. Питома вага первинної захворюваності була найбільшою у Берегівському районі (58,6 \%, 100 на 100 тис. нас.), а найменшою у Міжгірському (1,4\%, 4,2 на 100 тис. нас.). В Україні у 2017 році поширеність запальних захворювань ЦНС була меншою на 20,7 \%, ніж на Закарпатті [3].

У період сьогодення спостерігається зростання питомої ваги епілепсії в загальній структурі захворювань нервової системи з 0,5 \% до 0,8-1,2\% [2]. Дана тенденція робить вивчення епідеміології епілепсії вкрай актуальним. У Закарпатській області у 2017 році загальна захворюваність на епілепсію становила 160,3 на 100 тис. нас., а первинна - 8,4 на 100 тис. нас. (питома вага $-5,26 \%$ ). Найвищі значення поширеності мали місце в м. Ужгород (361,4 на 100 тис. нас.), Рахівському (162,9 на 100 тис. нас.) і Перечинському (153,6 на 100 тис. нас.) районах. Найменшу поширеність відмічено в Ужгородському (63,4 на 100 тис. нас.), Великоберезнянському (83 на 100 тис. нас.) і Свалявському (106 на 100 тис. нас.) районах. Питома вага первинної захворюваності на епілепсію була найбільшою у Мукачівському районі (16,3\%, 32,8 на 100 тис. нас.), і лише в одному Воловецькому районі у 2017 році не було зареєстровано нових випадків захворювання. У країні загалом поширеність епілепсії була меншою на 48,2 \% в порівнянні із Закарпаттям [3].

Поширеність, або в даному випадку первинна захворюваність, на минущі транзиторні церебральні ішемічні напади на Закарпатті у 2017 році становила 94,7 на 100 тис. нас. Показник первинної захворюваності був ідентичним у зв'язку із тим, що дана група розладів відноситься до гострих станів. Найвищі значення поширеності мали місце в Великобере- 
знянському (226,1 на 100 тис. нас.), Хустському (260,4 на 100 тис. нас.) і Виноградівському (161 на 100 тис. нас.) районах. Найменшу поширеність відмічено в Мукачівському (13,4 на 100 тис. нас.), Перечинському (25,1 на 100 тис. нас.) та Міжгірському (25,1 на 100 тис. нас.) районах.

У Закарпатській області у 2017 році поширеність хвороби Паркінсона становила 56,8 на 100 тис. нас. Показник первинної захворюваності був значно меншим - 4,3 на 100 тис. нас. (питома вага - 7,6 \%). Найвищі значення поширеності відмічались в м. Ужгород (157,9 на 100 тис. нас.), Великоберезнянському (154,7 на 100 тис. нас.) та Мукачівському (60,5 на 100 тис. нас.) районах. Найменші мали місце у Воловецькому (8,3 на 100 тис. нас.), Рахівському (28 на 100 тис. нас.) та Хустському (31,4 на 100 тис. нас.) районах. Питома вага первинної захворюваності на хворобу Паркінсона була найбільшою у Хустському районі (17,5 \%, 7,3 на 100 тис. нас.), а у Воловецькому та Рахівському районах нових випадків не зареєстровано.

Розсіяний склероз, виникаючи переважно у людей молодого віку, призводить до інвалідизації працездатного населення [2]. Його поширеність на Закарпатті у 2017 році становила 37,6 на 100 тис. нас. У свою чергу показник первинної захворюваності становив 2,4 на 100 тис. нас. (питома вага - 6,3\%). В Україні загалом поширеність розсіяного склерозу була 49,4 на 100 тис. нас. [3], тобто в 1,3 раза вищою, ніж на Закарпатті. Його поширеність була найбільшою в Мукачівському районі (76,5 на 100 тис. нас.), м. Ужгород (59,7 на 100 тис. нас.) і Перечинському районі (56,4 на 100 тис. нас.). Найменша поширеність мала місце у Воловецькому (24,8 на 100 тис. нас.), Виноградівському (33 на 100 тис. нас.) та Міжгірському (37,7 на 100 тис. нас.) районах. Питома вага первинної захворюваності була найбільшою в Ужгородському районі $(13,8 \%, 5,6$ на 100 тис. нас.). У трьох районах, а саме Великоберезнянському, Берегівському та Рахівському, нових випадків розсіяного склерозу не зареєстровано. В Україні у 2017 році поширеність розсіяного склерозу була більшою в 1,6 раза, ніж на Закарпатті [3].

Висновки. У ході дослідження виявлено, що в Закарпатській області відмічається подібна до України тенденція поширеності неврологічних захворювань, але значення показника на Закарпатті у 2017 році на 58,5 \% менше, ніж в країні загалом. Стосовно епідеміології окремих хвороб, то загальнообласні показники не відображають дійсний стан речей всередині області, так як в розрізі районів виявлено значні коливання значень показників як поширеності хвороб, так і первинної захворюваності, що може бути пов'язано 3 географічними та професійними особливостями даних місцевостей. Отримані дані можуть бути використані для оптимізації управління закладами охорони здоров'я на місцях.

\section{References:}

1. Khobzei MK, Zinchenko OM, Holubchykov MB, Mishchenko TC. Problema patolohii nervovoi systemy v Ukraini ta stan nevrolohichnoi sluzhby na mezhi desiatyrichchia. Zdorovia Ukrainy. Tematychnyi nomer. 2010; 3(14):3-4 [in Ukrainian].

2. Mishchenko TS. Epidemiolohiia zakhvoriuvan nervovoi systemy v Ukraini. Ukraïnskyi visnyk psykhonevrolohii. 2015; 23(3(84):151-152 [in Ukrainian].

3. Tsentr medychnoi statystyky MOZ Ukrainy. Pokaznyky zdorovia naselennia ta vykorystannia resursiv okhorony zdorovia v Ukraini za 2017 rik. Available from:

http://medstat.gov.ua/im/upload/ZAG_DOV_2017.zip

[Accessed 5th November 2018, in Ukrainian].

4. Smirnov MM, Zhornyk VV. Zakhvoriuvanist na mozkovi insulty v Zakarpatskii oblasti u 2017 rotsi. La science et la technologie à l'ère de la société de l'information: dcoll. de papiers scientifiques $« \Lambda \mathrm{O} О$ avec des matériaux de la conf. scientifique et pratique internationale, Bordeaux, 3 mars, 2019. Bordeaux: OP «Plateforme scientifique européenne»; 2019; 2:105-106 [in Ukrainian].

5. Kotvitska AA, Lobova IO. Otsinka epidemiolohichnoho stanu sudynno-mozkovykh zakhvoriuvan sered naselennia Ukraïny ta shliakhy yoho pokrashchennia. Upravlinnia, ekonomika ta zabezpechennia yakosti v farmatsii. 2013; 2(28):74-80 [in Ukrainian].

6. Tsentr medychnoi statystyky MOZ Ukrainy. Dovidnyk demohrafichnykh danykh po Ukraini za 2017 rik. Available from: http://medstat.gov.ua/im/upload/dem_dov17.zip [Accessed 4th November 2018, in Ukrainian].

7. Znamenska MA, Slabkyi HO. Analiz zakhvoriuvanosti ta poshyrenosti khvorob sered naselennia Ukrainy. Neonatolohiia, khirurhiia ta perynatalna medytsyna. 2015; 3(17):24-29 [in Ukrainian].

\section{УДК 616.8-936.22(477.87)"2017” \\ ЭПИДЕМИОЛОГИЯ НЕВРОЛОГИЧЕСКИХ ЗАБОЛЕВАНИЙ В ЗАКАРПАТСКОЙ ОБЛАСТИ В 2017 ГОДУ}

\section{И.М. Рогач, Н.Н. Смирнов, В.В. Жорник}

Ужсгородский национальный университет, кафедра соичиальной медиичны и гигиены,

2. Уэггород, Украина,

ORCID ID: 0000-0001-6112-3934,

ORCID ID: 0000-0002-9478-4787,

ORCID ID: 0000-0002-3795-2166,

e-mail: mykyta.smirnov@gmail.com

Резюме. Проблема неврологических заболеваний крайне важна: они принадлежат к наиболее распространенным заболеваниям XXI века, и большинство из них приводит к долговременным устойчивым неврологическим дефицитам. Изучение региональной эпидемиологии неврологической патологии может способствовать оптимизации управления учреждениями здравоохранения относительно данного вопроса и рациональному распределению имеющихся и потенциальных ресурсов. Целью нашего 
исследования было изучение и анализ эпидемиологии неврологических заболеваний среди взрослого населения Закарпатской области в 2017 году в контексте административно-территориальных единиц. Для получения информации о количестве случаев заболеваний и демографической обстановки нами были проанализированы отчеты (форма №12) учреждений здравоохранения, которые оказывали медицинскую помощь взрослому населению с неврологической патологией в Закарпатской области в 2017 году, и статистический бюллетень Главного управления статистики в Закарпатской области. На следующем этапе нами была подсчитана общая и первичная заболеваемость неврологической патологией с определением удельного веса последней и последующим анализом полученных показателей. В Закарпатской области отмечается подобная Украине тенденция распределения удельного веса отдельных групп заболеваний в структуре общей заболеваемости неврологической патологией. Значения показателей на Закарпатье в 2017 году были значительно ниже, чем в стране в целом. Распространенность неврологической патологии в общем составила 4902,4 на 100 тыс. нас. (на 58,8 \% меньше), цереброваскулярных заболеваний 2135,3 на 100 тыс. нас. (на 70,5 \% меньше), заболеваний нервной системы - 2767,1 на 100 тыс. нас. (на 40,6 \% меньше). Также отмечено значительные колебания значений показателей между районами области.

Ключевые слова: эпидемиология, неврологические заболевания, заболеваемость, взрослое население, распространенность.

\section{UDC 616.8-936.22(477.87)"2017" \\ EPIDEMIOLOGY OF NEUROLOGICAL DISORDERS IN THE TRANSCARPATHIAN REGION IN 2017}

\author{
I.M. Rogach, M.M. Smirnov, V.V. Zhornyk
}

Uzhhorod National University, Department of Social Medicine and Hygiene, Uzhhorod, Ukraine,

ORCID ID: 0000-0001-6112-3934,

ORCID ID: 0000-0002-9478-4787,

ORCID ID: 0000-0002-3795-2166,

e-mail:mykyta.smirnov@gmail.com

\begin{abstract}
The issue of neurological disorders is extremely important. These diseases belong to the most common ones of the 21 st century, and most of them lead to long-term persistent neurological deficits. According to the official data of the Center of Medical Statistics of the Ministry of Health of Ukraine, 4,497,718 patients with neurological disorders were registered in the country in 2017, which is $9 \%$ more than in $2014(4,130,479$ patients). The majority of them occur in a working age population and leads to prolonged temporary disability or even to permanent disability. Moreover, consequently,
\end{abstract}

these diseases indirectly affect the socio-economic development of a country.

Along with improvement in the quality and availability of diagnostics and treatment of neurological disorders, more important is to improve primary and secondary prophylaxis of these diseases and to create favorable environmental conditions for the life of an individual. Therefore, the study of regional epidemiology of neurological disorders may help to optimize management of health facilities regarding this issue and improve rational distribution of the available and potential resources.

The purpose of this research was to study and analyze the epidemiology of neurological disorders among adult population of the Transcarpathian region in 2017 in the context of its districts (administrative territorial units). To obtain the information about the number of cases of the diseases and the demographic situation in the investigated region we analyzed the reports (form No. 12) of health facilities, that provided medical care to adults with neurological disorders in the Transcarpathian region in 2017, and the statistical bulletin of the Main Department of Statistics in the Transcarpathian region. In our study, neurological disorders were defined as ones, which included the cerebrovascular diseases (I60-I69) and the diseases of the nervous system (G00-G99).

The prevalence and the cumulative incidence of neurological disorders were calculated with determination of share of the latter in the former. Then the subsequent analysis of the obtained indices was performed. The prevalence of neurological disorders was 4,902.4 per 100,000 (58.8\% less than federal index). The cerebrovascular diseases part was $2,135.3$ per 100,000 (70.5\% less) and the part of diseases of the nervous system was $2,767.1$ per $100,000(40.6 \%$ less $)$. In turn, the cumulative incidence of neurological disorders was $1,647.8$ per 100,000 with the distribution of 523 per 100,000 for the cerebrovascular diseases and 1,124.8 per 100,000 for the diseases of the nervous system. Apropos of the subgroups of diseases of the nervous system, the prevalence of diseases of the peripheral nervous system was 834.7 per 100,000 , of unspecified disorders of autonomous nervous system - 730.9 per 100,000 ; of inflammatory diseases of the central nervous system - 184.4 per 100,000 , of epilepsy -160.3 per 100,000 , of transient cerebral ischemic attacks - 94.7 per 100,000, of Parkinson's disease - 56.8 per 100,000 , of multiple sclerosis -37.6 per 100,000 .

It was defined that the tendencies of share distribution of the particular disease groups in the structure of the prevalence of neurological disorders in the Transcarpathian region in 2017 were similar to Ukraine, but the regional index values were lower than the federal ones. In addition, considerable fluctuations of the index values were observed among the administrative territorial units that may be due to their geographical and professional features.

Keywords: epidemiology, neurological disorders, cumulative incide

Стаття надійшла в редакцію 25.04.2019 р. 